O-244 脳卒中症例の排尿管理とFunctional Independence Measure(FIM)

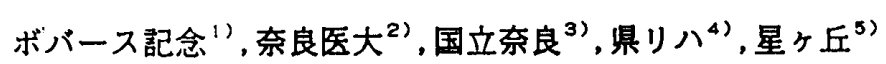

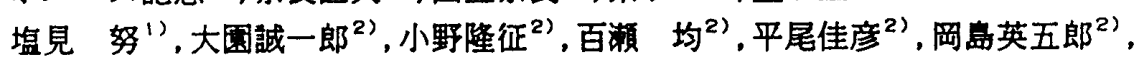

夏目 修 $^{3)}$, 安川元信 ${ }^{4}$, 平田直也 ${ }^{5)}$, 平山暁秀 ${ }^{51}$, 山本雅司 ${ }^{51}$, 山田 櫓 ${ }^{51}$

【目的】脂卒中の排尿管理においては、泌尿器科的因子に加えてADL因子、知的因子と環境因子が関わっ ている。近年、リハビリの治㩧効果の評価法を梳一するために機能的自立度評価法(FIM)が用いられ、現 場の臨床家により患者のセルフケア、排泄管理、移乗、移動、コミュニケーション、社会的認知能力に ついての統一スケールでの能力低下の評価が行われている。今回、我々は泌尿器科の排尿管理において ADL因子の評価にFIMを用いて総合的な解析を行った。【対象及び方法】1993年4月より1994年10月の間に 奈良紧立医科大学とその間連施設において排尿管理を行った脂卒中定例57例を対象とした。男性症例38 例、女性症例19例で平均年龄は64.8嘁、脳出血が22例、脑梗塞が33例、くも膜下出血が2例であった。リ ハビリ開始時で泌尿器科治療前とリハビリ後で泌尿器科治腺後においてFIMと洨尿器科的因子について 検討を行った。【結果】過活動性排尿筋の26定例で、18例に尿失禁を認め、排尿回数は14.0回/日で、膀 胱容量は108.3m1、残尿量は28.8m1であった。低活動性排尿筋は23例で、6例に尿失禁を認め、排尿回数 は11.4回/日で、耪胱容量は203.9m1、残尿量は60.7m1であった。正常排尿筋は8例で、3例に尿失禁を認

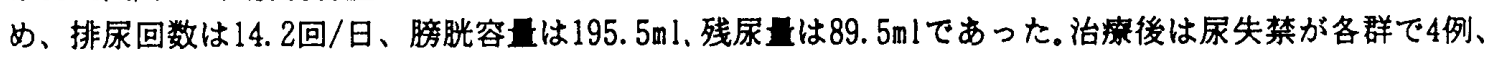
3例、2例となり、排尿回数は各群で9.1、8.2、9.0回/日となった。リハビリ前後でFIMが自立レべル(総 得点が108点以上)は10例が25例と增加し、部分介助レベル(37〜107点)は44例が32例、全介助レベル(36 点以下)は3例から0例になった。【結語】FIMは各項目が独立しており、得点により未连成の項目を特定 でき能力低下の総合的な評価が可能である。このため、ADL因子が大きく関与する脳卒中の排尿管理にお いては有用であった。

\title{
O-245 脳梗塞ラットの胯胱機能障害に対する蔡理学的検钨
}

金沢大学

石浦嘉之、横山修、中村靖夫、大川光央

【目的】䐉血管障害による排尿障害の病態は不明な点が多く、対症療法を行っているのが現状である。わ れわれはその病態の一部を解明すべく、脳梗塞ラットを用いて膀胱機能障害について検討した。【方法】 S-D種婎性ラットに、4-0ナイロン系を左側棇䅡動脈より㨉入、留置し、左側中大脳動脈項域を梗塞させ た。同時に膀腅偡を作成した。また、膀胱按のみを作成した群、左側総䅡動脈を桔禁した群も作成した。

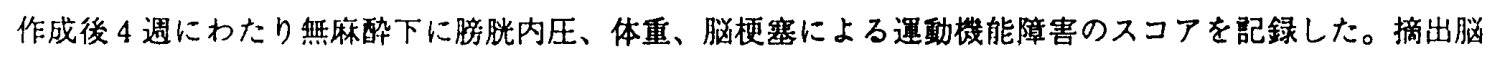
を塩化トリフェニルテトラゾリウム溶液で染色し、腷梗塞部位の同定および面皘測定を行った。利尿筋切 片に対し、 field stimulationによって生じる神释収縮をatropine および $\alpha, \beta$-methylene-ATPで前処監し記 録した。また、各種菜剂に対する膀胱利尿筋の反応性の変化も観察した。【結果】脳梗塞群は非脳梗塞群 と比較すると、4 週にわたり遇動機能障害と有意な膀胱容量の減少がみられ、特に 3 週以降の膀腅容量は 非脳梗塞群の 2 分の 1 以下であった。梗塞部位は左侧前頭葉、頭頂葉、被款であり、梗塞面稓と 1 週後の 湭胱容量との間には負の相関が認められた。末梢の神経筋刺激伝達に関し、コリン、プリン作動性神経の 構成比染に有意差はみられなかった。脑梗蹇群は偽手術群に比へ、 $\mathrm{KCl}$ 累皘適用による利尿筋切片の収縮 力の增大倾向が認められたが、有意差はみられなかった。【考察】脳梗寒群は非脳梗塞群と比較すると抗 コリン刘などの楽剂に対する反応性が增大している。これは、腷梗答により末梢レベルでの神程伝達系や 受容体に変化が坐したためと考えるより、排尿中枢の变化に起因していると推測された。この実験モアル

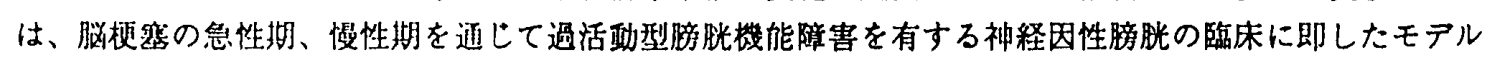
と考えられる。 